\title{
Distribution of Personal Protective Equipment to Health Workers in The Context of Handling The COVID-19 Pandemic in Bandung
}

\author{
Ragil Pardiyonoa), Gianti Puspawardhani, Hermita Dyah Puspita, \\ Oviyan Patra, Nurhadi, Rinto Yusriski, and Adi Ganda Putra
}

Industrial Engineering Study Program, Universitas Jenderal Achmad Yani, Bandung, Indonesia

${ }^{a}$ Corresponding Authoor : ragilpardiyono@gmail.com

\begin{abstract}
This community service distribution of personal protective equipment (PPE) is carried out to ease the burden on doctors and health workers in the fight against the Covid-19 pandemic. The success of this service is measured by the distribution of personal protective equipment for doctors and health workers. A total of 499 personal protective equipment was distributed to Dustira Cimahi Hospital, Hasan Sadikin Hospital Bandung, Muhammadiyah Hospital Bandung, Pindad Hospital Bandung, Kiara Condong Health Center Bandung and Sukapura Health Center Bandung. The evaluation of this activity is that it is necessary to carry out a similar service program to help communities affected by the pandemic
\end{abstract}

Keywords: Covid-19, Personal Protective Equipment, Health Workers.

\section{INTRODUCTION}

The latest threat to global health is the ongoing outbreak of a respiratory disease which has recently been named Coronavirus Disease 2019 (Covid-19). According to Fauci et al (2020) Covid-19 was recognized in December 2019 as structurally related to the virus that causes severe acute respiratory syndrome (SARS). The Covid-19 virus outbreak centered in Hubei Province, People's Republic of China, has spread to many other countries. On January 30, 2020, the WHO Emergency Committee declared a global health emergency based on the everincreasing rate of case notifications in China and international locations (Velavan \& Meyer, 2020). According to Pardiyono et al (2021) In early March 2020, Indonesia confirmed the first case of Coronavirus Disease-2019 (Covid-19) infection originating from China.

The Covid-19 pandemic in Indonesia has resulted in a very heavy burden on the health care system in the country, including health workers (Putri, 2020). The most visible risk is the safety aspect of health workers, especially those on the front lines, who are very vulnerable to being exposed to COVID-19 and are at risk of life threatening. Hundreds of doctors and other medical personnel have died from being infected with Covid-19 while carrying out health service duties.

In every country, regardless of their socioeconomic development, doctors and health workers are considered the front line in disease prevention and treatment of sufferers during and after treatment of any disease, including Covid-19 (Buheji \& Buhaid, 2020). The Coronavirus Disease-2019 severe acute respiratory syndrome pandemic has exposed doctors and health workers to the greatest potential. Therefore, the need for the use of personal protective equipment is increasing rapidly. According to WHO, personal protective equipment includes gloves, medical/surgical masks hereinafter referred to as "medical masks", goggles, face shields and gowns, as well as equipment for certain procedures, filter respirator masks (standard N95 or FFP2 or FFP3 or equivalent) hereinafter referred to as "respirator" and apron.

This personal protective equipment is also intended for officers involved in the distribution and management of personal protective equipment, as well as public health authorities and people in health and home care services who are involved in decisions regarding the use and prioritization of personal protective equipment. Personal protective equipment is like a shield and armor for medical personnel in the fight against Covid-19. Health workers are more susceptible to contracting Covid-19 than the general public because they have more frequent 
contact with infected people. Health workers are required to work under stressful conditions without proper personal protective equipment.

Due to the high demand for personal protective equipment, the supply of personal protective equipment for health workers in several hospitals is constrained. Therefore, the purpose of this community service is to provide personal protective equipment assistance to health workers in several hospitals in the city of Bandung.

\section{METHOD}

The implementation of this service partly follows the steps of Indrayani \& Pardiyono (2021). Materials and activity methods are designed to determine the type of community service, location, implementation and evaluation time.

1. Types of Community Service

Determination of the type of community service is carried out by means of a preliminary study of some of the impacts caused by the COVID-19 pandemic. A preliminary study is carried out by the team by means of interviews, as well as reading various references. Based on the results of the preliminary study, it was decided that community service to be carried out was the provision of personal protective equipment to doctors and health workers in several hospitals that were lacking.

In formulating this service activity through the following stages; planning activities with all teams to determine service targets. Then the implementation activities include surveys carried out to several hospitals with a large number of Covid 19 patients, then the implementation of the distribution of personal protective equipment. The last activity is an evaluation related to the implementation of service.

2. Determination of the Location of Service

Determination of the location of community service is based on the limitations of the team. In addition, there are also some restrictions due to government regulations that impose LargeScale and Micro-Scale Restrictions. Therefore, the location of the dedication of providing personal protective equipment to doctors and health workers in several hospitals in the city of Bandung.

3. Execution Time

The time for the distribution of personal protective equipment to doctors and health workers in several hospitals in the city of Bandung is on Saturday, September 19, 2020.

4. Evaluation, Evaluation is carried out to find out the obstacles and improvement of service activities in the future.

\section{RESULTS}

The success of this service is measured by the distribution of personal protective equipment for doctors and health workers. A total of 499 personal protective equipment was distributed to Dustira Cimahi Hospital, Hasan Sadikin Hospital Bandung, Muhammadiyah Hospital Bandung, Pindad Hospital Bandung, Kiara Condong Health Center Bandung and Sukapura Health Center Bandung. Complete data on recipients of personal protective equipment is presented in table 1 and figure 1 in the appendix. Pictures of service activities are also presented in the appendix.

\section{DISCUSSION}

At the initial stage, the selection of the type of service was carried out by means of interviews and literature studies through online media. The output of this activity concludes that the most urgent community service activity is to provide personal protective equipment for doctors and health workers. Then the determination of the location is considered a pandemic situation, then the location of service is decided only at hospitals in Bandung and Cimahi City.

The service was carried out on September 19, 2020. The distribution of aid was carried out in two ways, namely by direct delivery by a team with good health protocols and the second 
method by using an online delivery service (gosend). The evaluation of this activity is that it is necessary to carry out a similar service program to help communities affected by the pandemic.

\section{CONCLUSIONS AND RECOMMENDATIONS}

Community service activities by distributing personal protective equipment to health workers in the city of Bandung carried out by lecturers at the Faculty of Manufacturing Technology, Jenderal Achmad Yani University, Bandung went smoothly.

The success of this service is measured by the distribution of personal protective equipment for doctors and health workers. A total of 499 personal protective equipment was distributed to Dustira Cimahi Hospital, Hasan Sadikin Hospital Bandung, Muhammadiyah Hospital Bandung, Pindad Hospital Bandung, Kiara Condong Health Center Bandung and Sukapura Health Center Bandung.

\section{ACKNOWLEDGMENTS}

The first thanks to Allah SWT, author would like to thank the Dean of the Faculty of Manufacturing Technology, Universitas Jenderal Achmad Yani, who has helped the smooth running of this activity.

\section{REFERENCES}

Buheji, M., \& Buhaid, N. (2020). Nursing human factor during COVID-19 pandemic. International Journal of Nursing, 10(1), 12-24.

Fauci, A. S., Lane, H. C., \& Redfield, R. R. (2020). Covid-19-navigating the uncharted.

Indrayani, R., \& Pardiyono, R. (2021). PELATIHAN PEMANFAATAN PLAT NOMOR KENDARAAN BEKAS. Prosiding Penelitian Pendidikan dan Pengabdian 2021, 1(1), 654-658.

Pardiyono, R., Puspawardhani, G., Puspita, H. D., Putra, A. G., \& Yusriski, R. (2021). PENGABDIAN PADA MASYARAKAT TERDAMPAK PANDEMI COVID-19 DI BANDUNG. Prosiding Penelitian Pendidikan dan Pengabdian 2021, 1(1).

Putri, R. N. (2020). Indonesia dalam menghadapi pandemi Covid-19. Jurnal IImiah Universitas Batanghari Jambi, 20(2), 705-709.

Velavan, T. P., \& Meyer, C. G. (2020). The COVID-19 epidemic. Tropical medicine \& international health, 25(3), 278. 


\section{APPENDIX}

Table 1. Recipients of Personal Protective Equipment and Health Supplements

\begin{tabular}{clcc}
\hline No & \multicolumn{1}{c}{ Recipient } & $\begin{array}{c}\text { Personal protective } \\
\text { equipment } \\
\text { (package) }\end{array}$ & $\begin{array}{c}\text { Supplement } \\
\text { (dus) }\end{array}$ \\
\hline 1 & Dustira Hospital Cimahi & 133 & 20 \\
\hline 2 & Hasan Sadikin Hospital Bandung & 126 & 20 \\
\hline 3 & Muhammadiyah Hospital Bandung & 101 & 20 \\
\hline 4 & Pindad Hospital Bandung & 89 & 20 \\
\hline 5 & $\begin{array}{l}\text { Kiara Condong Health Center } \\
\text { Bandung }\end{array}$ & 25 & 10 \\
\hline 6 & Sukapura Health Center Bandung & 25 & 10 \\
\hline & \multicolumn{2}{r}{ Total } \\
\hline
\end{tabular}

\section{RECIPIENT HOSPITAL PERSONAL PROTECTIVE EQUIPMENT

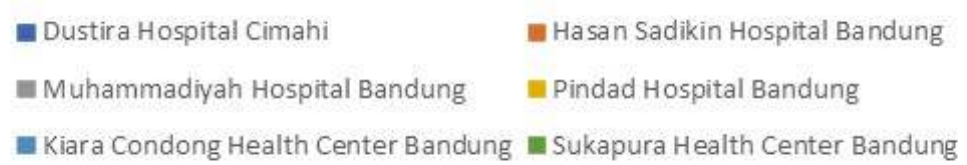

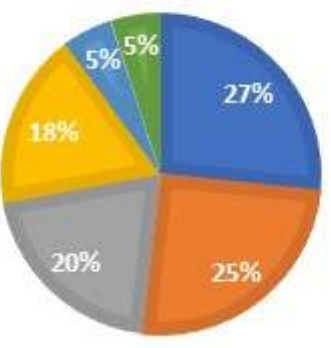

\section{RECIPIENT HOSPITAL SUPPLEMENT}

Dustira Hospital Cimahi Hasan Sadikin Hospital Bandung
Muhammadiyah Hospital Bandung
Miara Condong Health Center Bandung

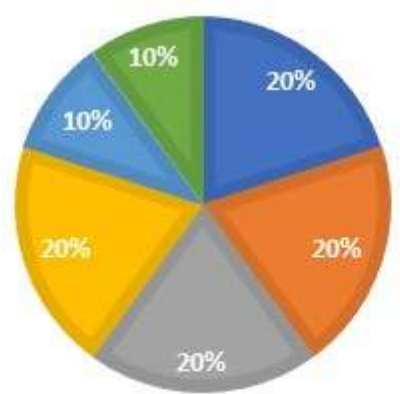

Figure 1. Graph of Number of Recipients of PPE and Health Supplements 


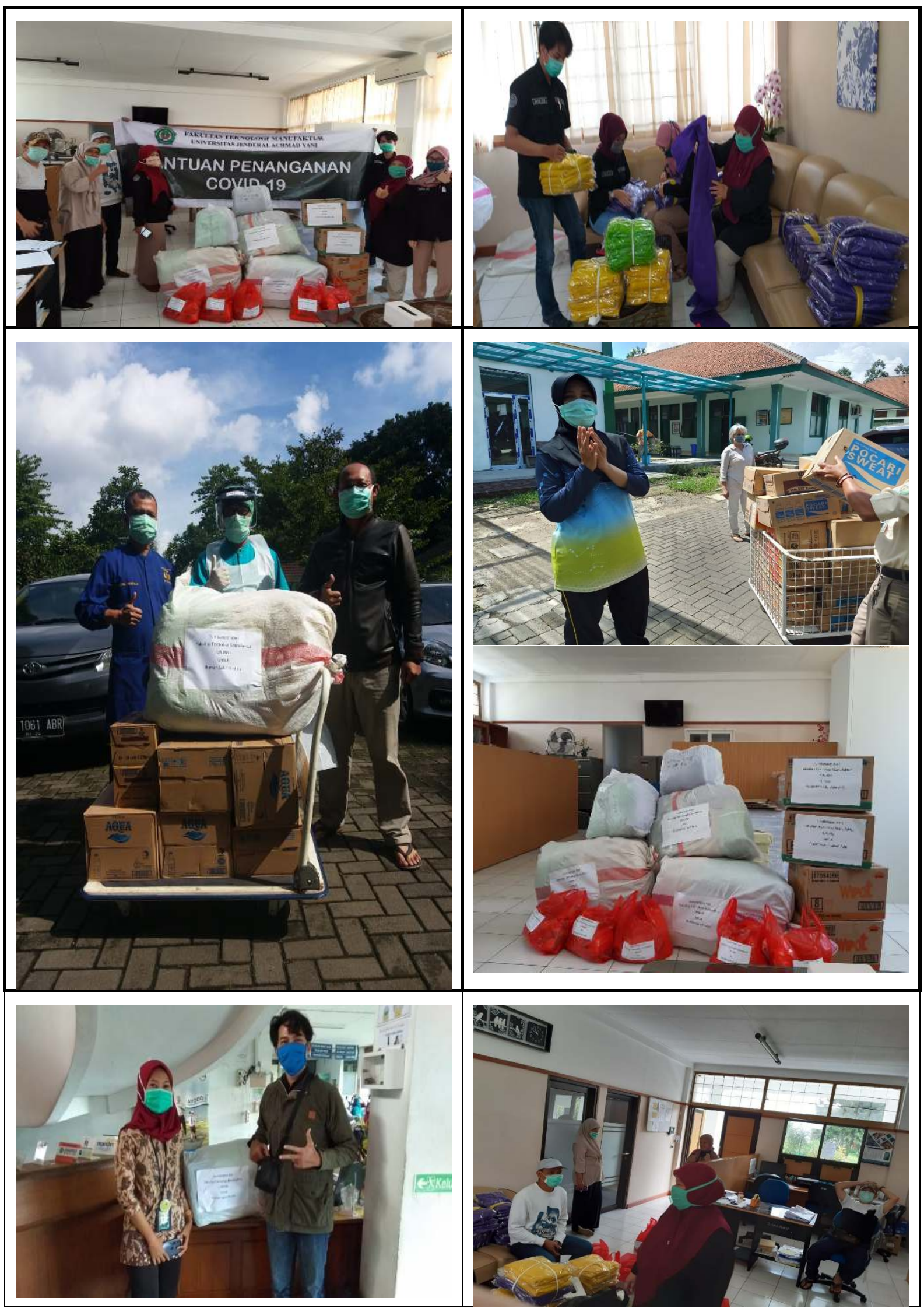

Figure 2. Handing over of personal protective equipment and supplements 


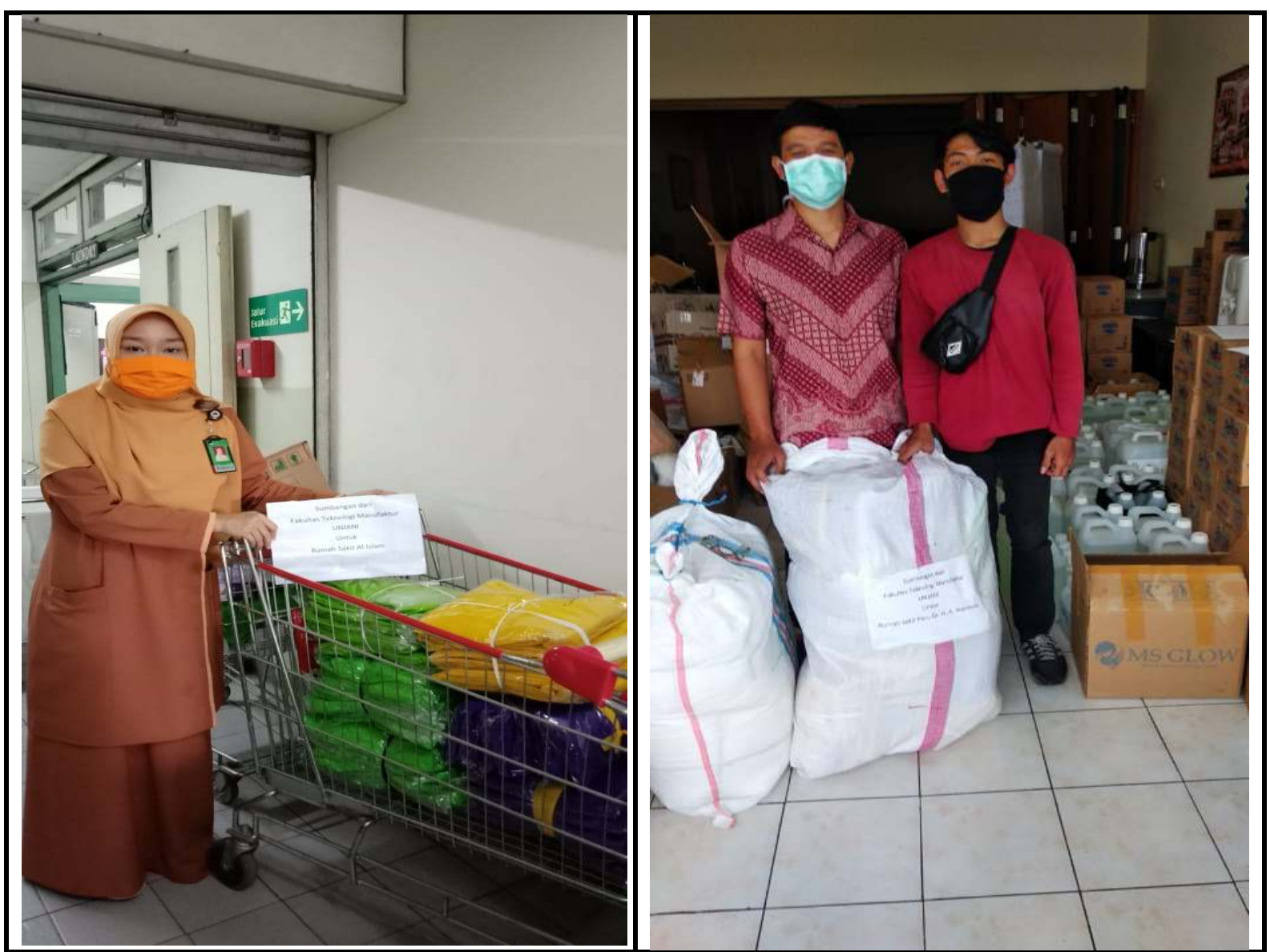

Figure 3. Handing over of personal protective equipment and supplements (Advanced) 